\title{
REVISED Case Report: Bone fragment in the third ventricle of a
}

\section{2 year-old woman [version 2; peer review: 2 approved, 1 not}

\section{approved]}

\author{
Sunil Munakomi (D), Balaji Srinivas, Iype Cherian (iD \\ International Society for Medical Education, College of Medical Sciences, Bharatpur, Chitwan, Nepal
}

V2 First published: 11 Mar 2015, 4:63

https://doi.org/10.12688/f1000research.6180.1

Latest published: 31 Mar 2015, 4:63

https://doi.org/10.12688/f1000research.6180.2

\section{Abstract}

Here we present a very rare case of a woman with a bone fragment in the third ventricle of the brain following compound-depressed skull fractures due to a road traffic accident.

There are only few case reports of bullets and textiloma being removed from the third ventricle. Following operative removal of the fragment, the patient was started on cortisol, mineralocorticoid and thyroid hormone replacement. However, the patient eventually died of the severe traumatic hypothalamic insult.

\section{Keywords}

bone fragment, brain surgery, compound-depressed fracture

\section{Open Peer Review \\ Approval Status \\ 1 \\ 2 \\ 3 \\ version 2 \\ (revision) \\ 31 Mar 2015

$\underset{\text { view }}{\checkmark} \quad \underset{v i e w}{\checkmark}$ \\ version 1 \\ 11 Mar 2015}

1. Andrey Belkin, Clinical Institute of the Brain, Ekaterinburg, Russian Federation

Alexey Pychteev, Clinical Institute of the Brain, Ekaterinburg, Russian Federation

2. Ajit Shrestha, National Institute of Neurological and Allied Sciences, Kathmandu, Nepal

3. Guo-Yi Gao, Shanghai Institute of Head

Trauma, Shanghai, China

Any reports and responses or comments on the article can be found at the end of the article. 
Corresponding author: Sunil Munakomi (sunilmunakomi@gmail.com)

Competing interests: No competing interests were disclosed.

Grant information: The author(s) declared that no grants were involved in supporting this work.

Copyright: @ 2015 Munakomi S et al. This is an open access article distributed under the terms of the Creative Commons Attribution License, which permits unrestricted use, distribution, and reproduction in any medium, provided the original work is properly cited.

How to cite this article: Munakomi S, Srinivas B and Cherian I. Case Report: Bone fragment in the third ventricle of a 22 year-old woman [version 2; peer review: 2 approved, 1 not approved] F1000Research 2015, 4:63

https://doi.org/10.12688/f1000research.6180.2

First published: 11 Mar 2015, 4:63 https://doi.org/10.12688/f1000research.6180.1 


\section{REVISED Amendments from Version 1}

We have revised and added the reason for opting to remove the depressed fracture despite its anatomical location.

See referee reports

\section{Case report}

A 22 year-old female, with no significant past medical and surgical illnesses, was brought to the casualty room with a Glasgow coma scale of $6 / 15$ following a collision between two bikes three hours earlier. Local examination revealed two compound depressed skull fractures in the frontal and the parietal region with egress of brain matter. Following primary resuscitation, computed tomography (CT) of the head confirmed the local findings along with the presence of one bone fragment in the third ventricle (Figure 1). The patient was taken for debridement of the wound and craniotomy circling the depressed sites. Since the patient was already extending and because there was already hemoventriculi, we opted for removal of the fragment despite its anatomical location so as to

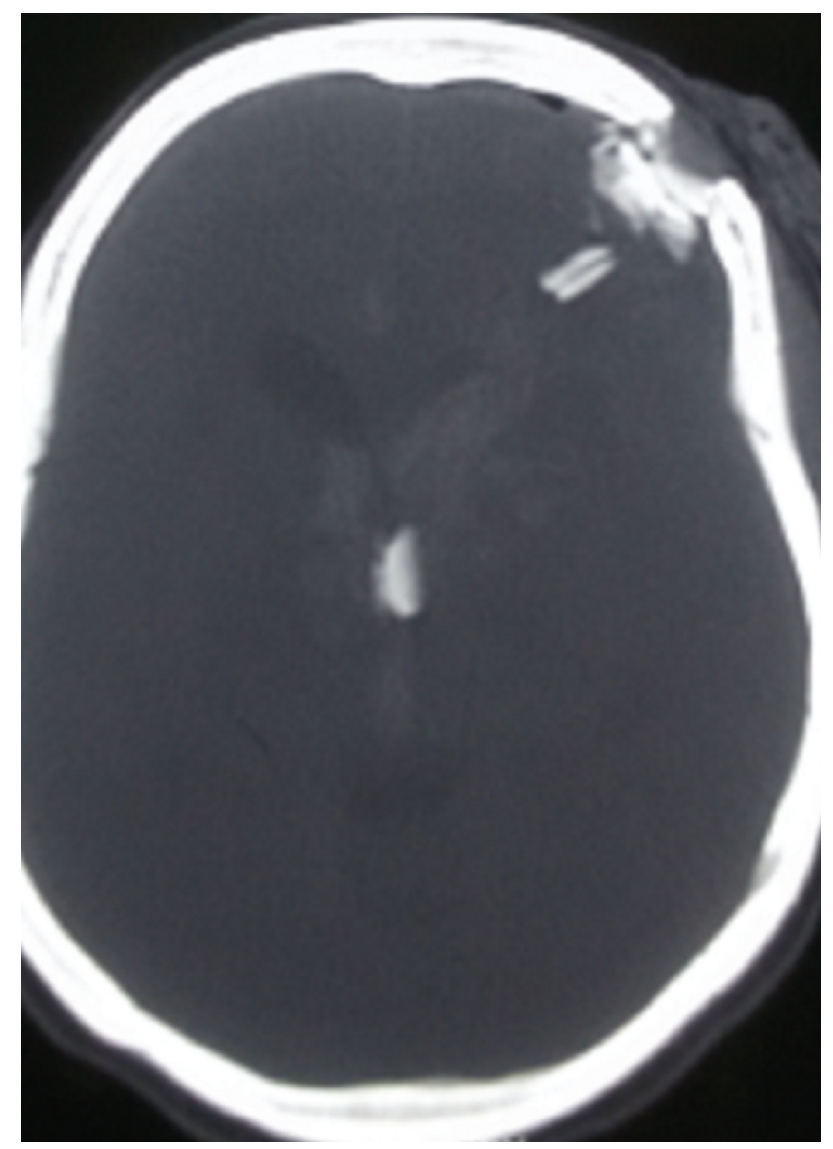

Figure 1. CT image showing the bone fragment lodged in the third ventricle. minimize further damage and chance of hydrocephalus. The bone fragment in the third ventricle was easily accessible following the hematoma track. An endoscope was also kept ready just in case the corridor to the fragment was difficult to access. Following retrieval of the bone fragment (Figure 2, Figure 3), intraventricular drain was placed and neurosurgical intensive care was provided. Repeated CT scans showed hypodensities around the third ventricle (Figure 4). On the second post-operative day, the patient was started on ionotropic support because of the refractory hypotension, and was also replaced with hydrocortisone, fludrocortisone and thyroid hormones. Wound dressing and the ventricular drain care was continued. Cerebrospinal fluid (CSF) culture from the drain resulted sterile. The patient died on the $8^{\text {th }}$ post-operative day because of the traumatic severe hypothalamic insult.

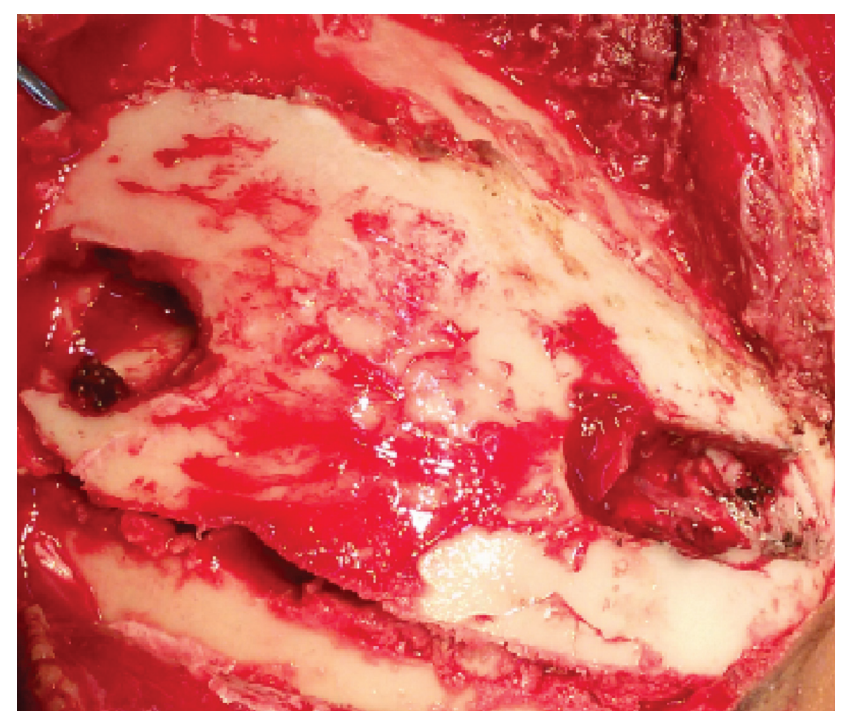

Figure 2. Intra-operative picture showing two sites of compound depressed fracture and the craniotomy performed circling both of them.

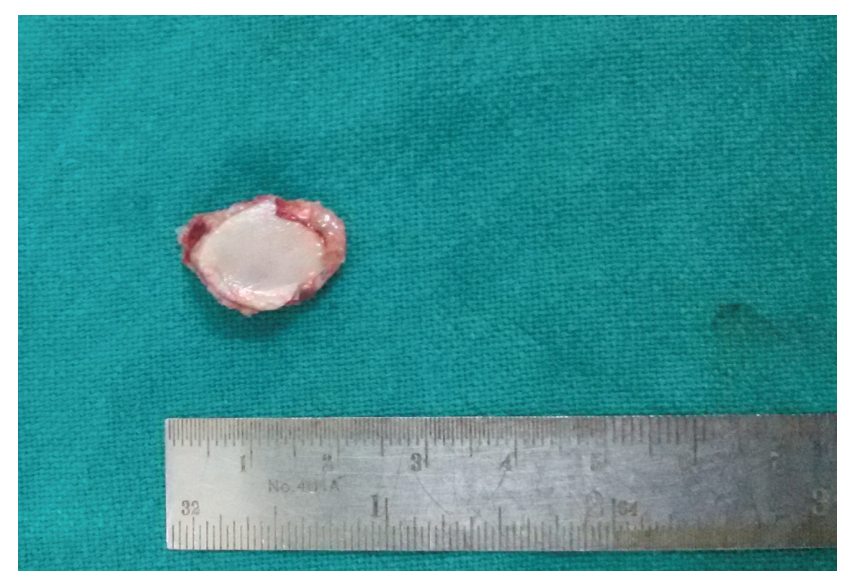

Figure 3. Image showing the bone fragment retrieved from the third ventricle. 


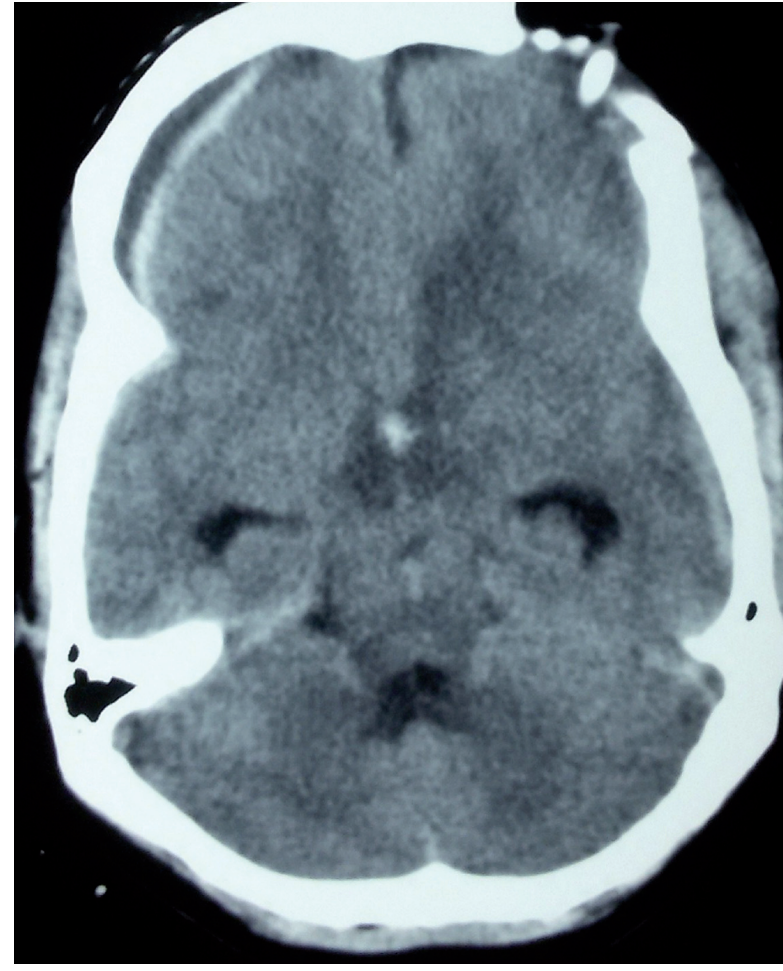

Figure 4. Post-operative image showing evidence of hypodensities surrounding hypothalamic region.

\section{Discussion}

As brain abscesses may result from driven bone fragments and other retained foreign bodies in the brain, the removal of readily accessible foreign bodies has received much attention ${ }^{3-6}$. Migration of foreign bodies can occur because of gravitational force. Other routes of migration can be subdural, parenchymal, transventricular or along streamlining along the white matter track ${ }^{7}$. The removal of foreign bodies is mostly done via craniotomy ${ }^{8,9}$, but other methods such as burr hole, stereotaxy ${ }^{10}$ and sometimes by ventriculoscopy ${ }^{11}$ have also been described.
The goals of modern treatments include removal of the foreign body under a controlled environment in the neurosurgical operation setting. Surgical principles include removal of bone fragments, intracerebral hematoma, control of hemorrhages and prevention of further loss of neural tissue. Patients should receive a broad spectrum intravenous antibiotic therapy along with tetanus prophylaxis. Monitoring and control of elevated intracranial pressure with maintenance of cerebral perfusion pressure plays a significant role in the patient's survival and outcome. The follow-up of such patients is essential, considering known complications like cerebrospinal fluid fistula in the early post-operative period and brain abscesses and seizures which may occur years after injury. Outcome after a penetrating head injury is directly related to the Glasgow coma scale at the time of presentation, which is the reflection of the extent of brain tissue damage caused directly by the primary impact. Intensive post-operative monitoring of intracranial pressure, cardio-respiratory function and metabolic status are required for optimizing the outcome of victims of penetrating craniocerebral injuries ${ }^{12}$. Penetrating head injuries have a higher mortality and morbidity than blunt trauma even in a civilian set up ${ }^{13}$. Even after timely removal of the penetrating objects and intensive medical management, the outcome may remain poor.

\section{Consent}

Informed written consent for publication of images and clinical details was obtained from the patient's husband.

\section{Author contributions}

Sunil Munakomi wrote and submitted the manuscript. Balaji Srinivas, Binod Bhattarai and Iype Cherian formatted and reviewed the paper.

\section{Competing interests}

No competing interests were disclosed.

\section{Grant information}

The author(s) declared that no grants were involved in supporting this work.
1. Greenwood J Jr: Removal of foreign body (bullet) from the third ventricle. J Neurosurg. 1950; 7(2): 169-72.

PubMed Abstract | Publisher Full Text

2. Lavrnic S, Stosic-Opincal T, Gavrilovic S, et al:: Intraventricular textiloma with granuloma formation following third ventricle colloid cyst resection - a case report. Cent Eur Neurosurg. 2009; 70(2): 86-8.

PubMed Abstract | Publisher Full Text

3. Carey ME, Young $\mathrm{H}$, Mathis $\mathrm{JL}$, et al.: A bacteriological study of craniocerebral missile wounds from Vietnam. J Neurosurg. 1971; 34(2 Pt 1): 145-154. PubMed Abstract | Publisher Full Text

4. Hagan RE: Early complications following penetrating wounds of the brain. J Neurosurg. 1971; 34(2 Pt 1): 132-141. PubMed Abstract | Publisher Full Text

5. Hammon WM: Analysis of $\mathbf{2 1 8 7}$ consecutive penetrating wounds of the brain from Vietnam. J Neurosurg. 1971; 34(2 Pt 1): 127-131.

PubMed Abstract | Publisher Full Text

6. Hammon WM: Retained intracranial bone fragments: analysis of 42 patients. J Neurosurg. 1971; 34(2 Pt 1): 142-144.

PubMed Abstract | Publisher Full Text

7. Rengarchy SS, Carey M, Templer J: The sinking bullet. J Neurosurg. 1992; 30(2):
291-294.

PubMed Abstract | Publisher Full Text

8. Campbell WP, Howard WO, Weary WB: Gunshot wounds of the brain. Report of two unusual complications: bifrontal pneumocephalus and a loose bullet in the lateral ventricle. Arch Surg. 1942; 44(5): 789-798. Publisher Full Text

9. Sternbergh WC Jr, Watts C, Clark K, et al:: Bullet within the fourth ventricle. Case report. J Neurosurg. 1971; 34(6): 805-807. PubMed Abstract | Publisher Full Text

10. Sujita K, Doi T, Sato O, et al.: Successful removal of intracranial air-gun bullet with stereotaxic apparatus. J Neurosurg. 1969; 30(2): 177-181. PubMed Abstract | Publisher Full Text

11. Dandy W: The brain. In: Lewis Practice of Surgery. Hagerstown, Md.: Wf Prior Co Inc. 1932; 12: Chap 1, 279-280.

12. Rosenberg WS, Harsh GR: Penetrating wounds of the head. In Williams, Rengachary, editors. Neurosurgery. New York: McGraw-Hill; 1996; 2813-9.

13. Black KL, Hanks RA, Wood DL, et al:: Blunt versus penetrating violent traumatic brain injury: frequency and factors associated with secondary conditions and complications. J Head Trauma Rehabil. 2002; 17(6): 489-96. PubMed Abstract | Publisher Full Text 


\section{Open Peer Review}

\section{Current Peer Review Status:}

\section{Version 2}

Reviewer Report 07 July 2015

https://doi.org/10.5256/f1000research.6785.r8885

(C) 2015 Gao G. This is an open access peer review report distributed under the terms of the Creative Commons Attribution License, which permits unrestricted use, distribution, and reproduction in any medium, provided the original work is properly cited.

\section{Guo-Yi Gao}

Department of Neurosurgery, Renji Hospital, Shanghai Institute of Head Trauma, Shanghai, China

I read this report with high interests not only for this is a rare case of bone fragment moved into the third ventricle, I am also impressed by the surgical efforts to remove it. Obviously it is a successful operation and it indicates the well trained neurosurgical technique of the surgeon. The fatal outcome resulted from the failure of hypothalamus function, which is still a problem to be solved in the future.

Competing Interests: No competing interests were disclosed.

I confirm that I have read this submission and believe that I have an appropriate level of expertise to confirm that it is of an acceptable scientific standard.

Reviewer Report 27 May 2015

https://doi.org/10.5256/f1000research.6785.r8705

(C) 2015 Shrestha A. This is an open access peer review report distributed under the terms of the Creative Commons Attribution License, which permits unrestricted use, distribution, and reproduction in any medium, provided the original work is properly cited.

\section{Ajit Shrestha \\ National Institute of Neurological and Allied Sciences, Kathmandu, Nepal \\ This is a rare case report from civilian society and is obviously will invite mixed school of thoughts. \\ The authors have wise reasons, obstructive hydrocephalus and infection, for removing the third ventricular bone fragment and, in doing so, has stated that the hematoma track, formed by the fragment traversing through the parenchyma, has been followed. The authors had made prudent decision by keeping neuroendoscope in hand for the removal of fragment in case of}


complications.

This report, I personally feel, encourages all trauma neurosurgeons to attempt removal of foreign body or possible source of infection or obstruction if it is accessible without undue further trauma to parenchyma.

Competing Interests: No competing interests were disclosed.

I confirm that I have read this submission and believe that I have an appropriate level of expertise to confirm that it is of an acceptable scientific standard.

\section{Version 1}

Reviewer Report 24 March 2015

https://doi.org/10.5256/f1000research.6625.r7934

(C) 2015 Belkin A et al. This is an open access peer review report distributed under the terms of the Creative Commons Attribution License, which permits unrestricted use, distribution, and reproduction in any medium, provided the original work is properly cited.

\section{Andrey Belkin}

Clinical Institute of the Brain, Ekaterinburg, Sverdlovsk region, Russian Federation

\section{Alexey Pychteev}

Clinical Institute of the Brain, Ekaterinburg, Sverdlovsk region, Russian Federation

It seems obvious that surgery even on symptomatic intracerebral foreign bodies is determined by the anatomical availability and physiological fact. In this case, initially, it seems that the risk of surgery was higher than the risk of complications due to the presence of a foreign body and, therefore, the intervention was not justified.

In order to give a more detailed review we would need to have a tomogram data on the patient's condition. Based on the currently available outline of the situation, this patient would require more conservative treatment (aggressive antibiotic therapy in the presence of the slightest signs of SIRS or antibiotic prophylaxis from the first hours).

Only if the patient on admission had a detailed diencephalic syndrome (and judging by the description they did not) and clinical signs of meningitis, would we try endoscopic removal of the foreign body (if it is of small size, somewhere up to $1 \mathrm{~cm}$ ). Thus one alternative conservative intervention is to attempt endoscopic evacuation.

If endoscopic evacuation is not possible (large size foreign bodies, technical inaccessibility through the ventricle), another possible surgical action that I would have done (but only in the case of ventriculitis) is external ventricular drainage. No more. 
Competing Interests: No competing interests were disclosed.

We confirm that we have read this submission and believe that we have an appropriate level of expertise to state that we do not consider it to be of an acceptable scientific standard, for reasons outlined above.

The benefits of publishing with F1000Research:

- Your article is published within days, with no editorial bias

- You can publish traditional articles, null/negative results, case reports, data notes and more

- The peer review process is transparent and collaborative

- Your article is indexed in PubMed after passing peer review

- Dedicated customer support at every stage

For pre-submission enquiries, contact research@f1000.com 